\title{
Exploring the possibility to store the mixed oxygen-hydrogen cluster in clathrate hydrate in molar ratio 1:2 $\left(\mathrm{O}_{2}+2 \mathrm{H}_{2}\right)$
}

\author{
Yan Qin ${ }^{1}$, Qi-Shi Du ${ }^{1,2^{*}}$, Neng-Zhong Xie ${ }^{1}$, Jian-Xiu Li ${ }^{1}$, Ri-Bo Huang ${ }^{1}$ \\ ${ }^{1}$ National Engineering Research Center for Non-food Biorefinery, State key \\ Laboratory of Bioenergy Enzyme Technology, Guangxi Academy of Sciences, \\ Nanning, Guangxi, 530007, China \\ ${ }^{2}$ Gordon Life Science Institute, 53 South Cottage Road, Belmont, MA 02478, USA
}

Corresponding authors:

E-mail: duqishi@ foxmail.com (Q.-S. D.)

*Tel/Fax: 086-771-250-3931/086-771-250-3908

Short title: Mixed storage of $\mathrm{O}_{2}+2 \mathrm{H}_{2}$ in hydrate cell

Key words: Clathrate hydrate; Hydrogen storage; $\mathrm{O}_{2}-2 \mathrm{H}_{2}$ mixed storage; Gas-hydrate stability; Escaping energy 


\begin{abstract}
An interesting possibility is explored: storing the mixture of oxygen and hydrogen in clathrate hydrate in molar ratio 1:2. The interaction energies between oxygen, hydrogen, and clathrate hydrate are calculated using high level quantum chemical methods. The useful conclusion points from this study are summarized as follows. (1) The interaction energies of oxygen-hydrogen mixed cluster are larger than the energies of pure hydrogen molecular cluster. (2) The affinity of oxygen molecules with water molecules is larger than that of the hydrogen molecules with water molecules. (3) The dimension of $\mathrm{O}_{2}-2 \mathrm{H}_{2}$ interaction structure is smaller than the dimension of $\mathrm{CO}_{2}-2 \mathrm{H}_{2}$ interaction structure. (4) The escaping energy of oxygen molecules from the hydrate cell is larger than that of the hydrogen molecules. (5) The high affinity of the oxygen molecules with both the water molecules and the hydrogen molecules may promote the stability of oxygen-hydrogen mixture in the clathrate hydrate. Therefore it is possible to store the mixed $\left(\mathrm{O}_{2}+2 \mathrm{H}_{2}\right)$ cluster in clathrate hydrate.
\end{abstract}

Key words: Clathrate hydrate; Hydrogen storage; $\mathrm{O}_{2}-2 \mathrm{H}_{2}$ mixed storage; Gas-hydrate stability; Escaping energy 


\section{Introduction}

The gas clathrate hydrates exist in the natural world in large scale [1-3]. The most abundant gas hydrate is the methane-hydrates, which are buried in the continental shelf, constituting the earth's largest energy resource, more than twice the amount of all other fossil energy, including petroleum, natural gas and coal in the continents [1-3]. The hydrate $5^{12}$ cell is the smallest and basic unit of clathrate hydrate. The structure of $5^{12}$ hydrate cell is shown in Fig 1, which is a dodecahedron consisting of 20 hydrogen-bond bound water molecules in 12 pentagon faces [4]. The average experimental side length (distance between two neighboring oxygen atoms) of the methane-hydrate is $\mathrm{R}_{\mathrm{O}-\mathrm{O}}=2.82 \AA$ and the diameter of $5^{12}$ hydrate cell is $7.92 \AA$ [1].

(Figure 1)

In recent years the gas hydrates have been considered for potential applications in clear energy, space exploration, environmental and ecological protections [5-11]. The carbon dioxide $\left(\mathrm{CO}_{2}\right)$ was suggested to be trapped in the clathrate hydrate and buried in the ocean floor in order to solve the global warming problem [12,13]. The clathrate hydrate was proposed to store hydrogen molecules $\left(\mathrm{H}_{2}\right)$ as clean fuel for automobiles, space rockets and shuttles [14-17].

Hydrogen molecules $\left(\mathrm{H}_{2}\right)$ stored in clathrate hydrate was first reported in 2002, but requires very high pressures to be stable [14]. In order to store hydrogen molecules in lower pressure, the larger promoter molecules, such as tetrahydrofuran (THF) $[15,18]$ and tetrabutyl ammonium bromide (TBAB) [19], are introduced. In 2004 the experiment by Sloan and colleagues showed that the solid $\mathrm{H}_{2}$-containing hydrates could be formed at ambient temperature and tens of bar by adding small amounts of promoting substance tetrahydrofuran (THF) [20-23]. On the other hand the partner molecules (such as $\mathrm{CO}_{2}$ and $\mathrm{SF}_{6}$ ) are used to help the storage of hydrogen molecules in clathrate hydrate. The $\mathrm{H}_{2}-\mathrm{CO}_{2}$ mixed hydrates were reported by Kim [24], Grim [25], and Kumar [26], respectively. Unlike promoter molecules, which occupy the hydrate cells alone, the partner molecules may share the same hydrate cells with hydrogen molecules. 
In many fields we need both oxygen as oxidant and hydrogen as deoxidizer. For example, in space travels the rockets and shuttles need the hydrogen molecules as the fuel and the oxygen molecules as the oxidant. Usually the oxygen and hydrogen were stored separately. The mixed storage of oxygen molecules and hydrogen molecules may have enormous advantages over the traditional storages separately, because less containers and equipments are used. However, in ordinary condition the mixed storage of hydrogen molecules and oxygen molecules is extremely dangerous because of the violent reaction between oxygen molecules and hydrogen molecules, which may cause serious explosion.

In order to solve the problem of oxygen-hydrogen mixed storage, the clathrate hydrate may be a useful method. If one oxygen molecule and two hydrogen molecules are trapped in a small hydrate cell, the chemical reaction is almost impossible, because such reaction needs very high activation energy, or frequent collision among thousands oxygen and hydrogen molecules. If no platinum catalysis, the explosion reaction of oxygen and hydrogen in the hydrate cells almost wouldn't happen.

Molecular modeling $[27,28]$ is a powerful tool in the study of clathrate hydrates $[4$, 29]. In this study the possibility of oxygen and hydrogen mixed storage in clathrate hydrates is explored using computational chemistry methods. The results and conclusions from this study may open an effective approach for clean energy, transportation, space travel, and submarine navigation in ocean.

\section{Results}

In the storage of hydrogen in clathrate hydrate the typical partner molecules are $\mathrm{CO}_{2}$ and $\mathrm{SF}_{6}$. Usually the partner molecules possess higher affinity with both water molecules and hydrogen molecules, which may enhance the stability of hydrogen molecular cluster in hydrate cells. The oxygen molecules could be a good molecular partner for hydrogen storage in clathrate hydrate. The reasons and evidences for above prediction will be presented in this study.

\subsection{Interaction energies of small molecular clusters}


The interaction energies inside the molecular clusters in gaseous phase are calculated using three methods MP2 [30-32], CCSD [33], and CCSD(T) [33,35] with basis set cc-pV5Z [35,36]. The calculation results are listed in Table 1, and the optimized interaction structures are shown in Fig 2. The interaction energies of four hydrogen and oxygen clusters $\left(2 \mathrm{H}_{2}, 3 \mathrm{H}_{2}, \mathrm{O}_{2}-\mathrm{H}_{2}\right.$, and $\left.\mathrm{O}_{2}-2 \mathrm{H}_{2}\right)$ are listed in Table 1. For comparison the interaction energies between hydrogen and carbon dioxide $\left(\mathrm{CO}_{2}-\mathrm{H}_{2}\right.$ and $\mathrm{CO}_{2}-2 \mathrm{H}_{2}$ ) are also listed in Table 1. The results of MP2 method are better than that of CCSD, little poorer than the results of the state-of-the art method CCSD(T). However, the results of MP2 method are consistent with the CCSD(T) method and uses much less CPU-time than the CCSD(T) method.

\section{(Table 1 and Figure 2)}

The optimized interaction structure of $\mathrm{O}_{2}-\mathrm{H}_{2}$ is in ' $\mathrm{T}$ ' form (Fig 2 B), in which the $\mathrm{H}_{2}$ perpendicularly points to the center of the $\mathrm{O}_{2}$ molecule. The optimal structure of $\mathrm{H}_{2}-\mathrm{H}_{2}$ is basically the ' $\mathrm{T}$ ' form (Fig 2 A). However, the dihedral angle $\left(\mathrm{D}_{1,2,3}^{2,3,4}\right)$ between the four hydrogen atoms is $177.65^{\circ}$, and the angle formed by the two hydrogen molecules and the center of the other $\mathrm{H}_{2}$ molecule is $173.13^{\circ}$. The optimized interaction structure of $\mathrm{O}_{2}-2 \mathrm{H}_{2}$ cluster is the cross form ' + ' (Fig 2 C), in which the two $\mathrm{H}_{2}$ molecules perpendicularly point to the center of oxygen molecule $\left(\mathrm{O}_{2}\right)$. The dimension of the $\mathrm{O}_{2}-2 \mathrm{H}_{2}$ cross interaction structure is $7.354 \AA$ that is very difficult to be put in the $5^{12}$ hydrate cell, whose diameter is $7.92 \AA$ (see Fig 1). A scanning calculation is performed for the angle $\angle \mathrm{H}_{2}-\mathrm{O}_{2}-\mathrm{H}_{2}$, and the curve of $\mathrm{O}_{2}-2 \mathrm{H}_{2}$ interaction energy $\Delta E_{\text {clst }}$ as function of angle $\angle \mathrm{H}_{2}-\mathrm{O}_{2}-\mathrm{H}_{2}$ is shown in Fig 3. In the energy curve there are two local minimums $\left(-3.002 \mathrm{~kJ} / \mathrm{mol}\right.$ at $63^{\circ}$ and $\left.297^{\circ}\right)$. The $\mathrm{O}_{2}-2 \mathrm{H}_{2}$ interaction structure at the local minimum is shown in Fig 2 D. The dimension $3.709 \AA \times 3.842 \AA$ of the $\mathrm{O}_{2}-2 \mathrm{H}_{2}$ interaction structure at local minimum is suitable to be put in the $5^{12}$ hydrate cell.

(Figure 3)

In Table 1 the interaction energies of pure hydrogen molecular clusters $\left(2 \mathrm{H}_{2}\right.$ and $3 \mathrm{H}_{2}$ ) are very weak, less than $1 \mathrm{~kJ} / \mathrm{mol}$. The interaction energies of oxygen-hydrogen 
clusters $\mathrm{O}_{2}-\mathrm{H}_{2}$ and $\mathrm{O}_{2}-2 \mathrm{H}_{2}$ are much larger than that of pure $\mathrm{H}_{2}$ clusters, very close to that of the $\mathrm{CO}_{2}-\mathrm{H}_{2}$ and $\mathrm{CO}_{2}-2 \mathrm{H}_{2}$ clusters. However, the dimension $(9.543 \AA$ ) of $\mathrm{CO}_{2}-2 \mathrm{H}_{2}$ interaction structure is much larger than the diameter $(7.92 \AA)$ of $5^{12}$ hydrate cell (see Fig 1 A and Fig 2 E).

\subsection{Interaction energies of $\mathrm{H}_{2}, \mathrm{O}_{2}$ and $\mathrm{CO}_{2}$ with water molecules}

The interaction energies and structural parameters of three types of molecules $\left(\mathrm{H}_{2}, \mathrm{O}_{2}\right.$, and $\left.\mathrm{CO}_{2}\right)$ with water molecule $\left(\mathrm{H}_{2} \mathrm{O}\right)$ are calculated at the CCSD(T)/cc-pV5Z level. The calculation results are listed in Table 2, and the optimized interaction structures are shown in Fig 4. The interaction energy $(-8.662 \mathrm{~kJ} / \mathrm{mol})$ of $\mathrm{H}_{2} \mathrm{O}-\mathrm{O}_{2}$ cluster is much larger than that $(-0.5101 \mathrm{~kJ} / \mathrm{mol})$ of $\mathrm{H}_{2} \mathrm{O}-\mathrm{H}_{2}$ cluster, and reached the $2 / 3$ of the interaction energy $(-12.719 \mathrm{~kJ} / \mathrm{mol})$ of $\mathrm{H}_{2} \mathrm{O}-\mathrm{CO}_{2}$ cluster. The solubility of $\mathrm{H}_{2}, \mathrm{O}_{2}$, and $\mathrm{CO}_{2}$ are listed in Table 2. In aqueous solution the solubility of oxygen molecules is 26 times higher than the solubility of hydrogen molecules, very close to the concentration of $\mathrm{CO}_{2}$ in water. Therefore, oxygen molecules possess larger affinity with the water molecules than that of hydrogen molecules. The higher affinity of oxygen molecules with both the hydrogen molecules and the water molecules may enhance the stability of hydrogen molecules in the clathrate hydrate.

(Table 2 and Figure 4)

\subsection{Stable energies of guest molecular clusters in hydrate cell}

The interaction energies $\Delta E_{\text {cell-clst }}$ between the hydrate cell and the guest molecular cluster and the stable energies $\Delta E_{\text {stable }}$ of the gas-hydrate cell are calculated using $\mathbf{E q} 3$ and Eq 5 (see Method section), respectively, and the results are listed in Table 3. From the data in Table 3 two phenomena are observed. (1) The cell-cluster interaction energies $\Delta E_{\text {cell-clst }}$ are larger than the gas-hydrate stable energies $\Delta E_{\text {stable. }}$ As evaluated by the $\mathbf{E q} \mathbf{5}$, the gas-hydrate stable energy $\Delta E_{\text {stable }}$ is the sum of the cell-cluster interaction energies $\Delta E_{\text {cell-clst }}$ and the cluster interaction energy $\Delta E_{\text {clst }}$ : $\Delta E_{\text {stable }}=\Delta E_{\text {cell-clst }}+\Delta E_{\text {clst. }}$ In many cases the guest cluster interaction energies $\Delta E_{\text {clst }}$ are repulsive (positive values) because of the small room and the high electrostatic 
potential in hydrate cells. (2) The gas-hydrate stable energies $\Delta E_{\text {stable }}$ and the cell-cluster interaction energies $\Delta E_{\text {cell-clst }}$ of the mixed oxygen-hydrogen clusters $\left(\mathrm{O}_{2}-\mathrm{H}_{2}\right.$ and $\left.\mathrm{O}_{2}-2 \mathrm{H}_{2}\right)$ are remarkably larger than that of the pure hydrogen molecular clusters $\left(2 \mathrm{H}_{2}\right.$ and $\left.3 \mathrm{H}_{2}\right)$. A reasonable explanation is that the higher affinity of oxygen molecules with both hydrogen molecules and water molecules promotes the stability of the clathrate hydrate of oxygen-hydrogen mixture.

(Table 3)

\subsection{Thermodynamic and frequency calculations}

Thermodynamic calculations are performed for studying the contributions of inner energies, thermal enthalpies and entropies, including the zero-point correction and other corrections. For comparison the frequency calculations are carried out at $273 \mathrm{~K}$ $\left(0^{\circ} \mathrm{C}\right)$ using B3LYP/6-311+G(d,p) method for guest molecular cluster $\left(\mathrm{O}_{2}+2 \mathrm{H}_{2}\right)$ and $\left(\mathrm{CO}_{2}+2 \mathrm{H}_{2}\right)$ in $5^{12}$ hydrate cell, respectively. The results of frequency calculations are summarized in Table 4.

\section{(Table 4)}

In $5^{12}$ hydrate cell although the guest-host interaction energy $\Delta U^{\circ}$ and enthalpy $\Delta H^{\circ}$ of $\left(\mathrm{CO}_{2}+2 \mathrm{H}_{2}\right)$ cluster are larger than that of $\left(\mathrm{O}_{2}+2 \mathrm{H}_{2}\right)$ cluster, the guest-host interaction free energy $\Delta G^{\circ}\left(\mathrm{O}_{2}+2 \mathrm{H}_{2}\right)=-782.40 \mathrm{~kJ} / \mathrm{mol}$ of $\left(\mathrm{O}_{2}+2 \mathrm{H}_{2}\right)$ cluster is much larger than $\Delta G^{\circ}\left(\mathrm{CO}_{2}+2 \mathrm{H}_{2}\right)=-320.64 \mathrm{~kJ} / \mathrm{mol}$ of $\left(\mathrm{CO}_{2}+2 \mathrm{H}_{2}\right)$ cluster. The reason is that in $5^{12}$ hydrate cell the guest cluster $\left(\mathrm{CO}_{2}+2 \mathrm{H}_{2}\right)$ encounters larger repulsive interaction than $\left(\mathrm{O}_{2}+2 \mathrm{H}_{2}\right)$ cluster does.

\subsection{Escaping energies of $\mathrm{O}_{2}$ and $\mathrm{H}_{2}$ molecules from hydrate cell}

Could the hydrogen and oxygen molecules escape from the clathrate hydrate cells? The escaping energies $\Delta E_{\text {escape }}(\mathrm{r})$ of the hydrogen and oxygen molecules from the $5^{12}$ hydrate cell are calculated using Eq 6 (see Method section). The escaping energies $\Delta E_{\text {escape }}(\mathrm{r})$ of hydrogen molecule and oxygen molecule are the functions of the distance $r$ between the center of $5^{12}$ hydrate cell and the position of guest molecule $\left(\mathrm{H}_{2}\right.$ or $\left.\mathrm{O}_{2}\right)$, as shown in Fig 5. 
(Figure 5)

Based on the MP2/6-311+G (d, p) [32] calculations, the escaping energy barrier of hydrogen molecule from the $5^{12}$ hydrate cell is $74 \mathrm{~kJ} / \mathrm{mol}$ at the distance $\mathrm{R}=3.8 \AA$. The escaping energy barrier of oxygen molecule is $152.5 \mathrm{~kJ} / \mathrm{mol}$ at $\mathrm{R}=3.2 \AA$, much higher than that of the hydrogen molecule. Therefore the mixture of oxygen and hydrogen molecules may stabilize the storage of hydrogen molecules in clathrate hydrates.

\section{Discussion}

The large promoter molecules, such as tetrahydrofuran (THF) $[15,18]$ and tetrabutyl ammonium bromide (TBAB) [19], can help the storage of $\mathrm{H}_{2}$ molecules in hydrate cells at moderate pressure and temperature. However, it is very difficult to achieve high capacity by using the promoter molecules, because the promoter molecules being larger in size preferably occupies the large cavities, thus only small cells are available for hydrogen molecules, which significantly reduces the storage capacity. Unlike the promoter molecules THF and TBAB, in the mixed storage the $\mathrm{O}_{2}-2 \mathrm{H}_{2}$ cluster may occupy the same cells in the clathrate hydrate, including the small cells and large cells, without the losing of the storage capacity.

On the other hand, the $\mathrm{O}_{2}-2 \mathrm{H}_{2}$ mixed storage is different from the co-guest storage, such as $\mathrm{SF}_{6}+\mathrm{H}_{2}, \mathrm{CO}_{2}+\mathrm{H}_{2}$, and other co-guest molecules [9,39-42]. In the $\mathrm{O}_{2}+2 \mathrm{H}_{2}$ mixed storage the partner molecules $\mathrm{O}_{2}$ are an important component in the high density energy materials, as important as the hydrogen molecules. In contrast, the partner molecules $\mathrm{CO}_{2}$ and $\mathrm{SF}_{6}$ are waste for energy purpose, and toxin to environmental protection.

\section{Conclusion}

Some useful conclusions are summarized as follows. (1) The interaction energies of the oxygen-hydrogen mixed clusters are larger than the interaction energies in pure hydrogen molecular clusters. (2) The affinity of oxygen molecules with water molecules is larger than the affinity of the hydrogen molecules with the water 
molecules. (3) The dimension of $\mathrm{O}_{2}-2 \mathrm{H}_{2}$ interaction structure is smaller than the dimension of $\mathrm{CO}_{2}-2 \mathrm{H}_{2}$ interaction structure. (4) The escaping energy barrier of oxygen molecules from the hydrate cell is larger that of the hydrogen molecules. (5) The high affinity of the oxygen molecules with both the water molecules and the hydrogen molecules may promote the stability of oxygen-hydrogen mixture in the clathrate hydrate. Therefore it is possible to store the mixed $\left(\mathrm{O}_{2}+2 \mathrm{H}_{2}\right)$ cluster in clathrate hydrate. The $\left(\mathrm{O}_{2}+2 \mathrm{H}_{2}\right)$ mixed storage in clathrate hydrate may find potential applications in several fields, such as transportation, submarine, and space travel [43].

\section{Theory and Method}

The practical experiments to store the oxygen and hydrogen mixture $\left(\mathrm{O}_{2}+2 \mathrm{H}_{2}\right)$ in the clathrate hydrate may be very difficult. However, exploring the possibility of mixed hydrogen-oxygen storage using computational chemistry is relatively easy. Quantum chemistry modeling the gas hydrates has been carried out by several authors $[4,44,45]$. In this study the state-of-the art method $\operatorname{CCSD}(T)[34,35]$ is used in the calculations of guest molecular clusters $\left(\mathrm{nH}_{2}, \mathrm{O}_{2} / \mathrm{H}_{2}\right.$ and $\left.\mathrm{CO}_{2} / \mathrm{H}_{2}\right)$, MP2 [30-32] method is applied in the calculations of guest molecules $\left(\mathrm{nH}_{2}, \mathrm{O}_{2} / \mathrm{H}_{2}\right.$ and $\left.\mathrm{CO}_{2} / \mathrm{H}_{2}\right)$ in $5^{12}$ hydrate cell. In the enthalpy and free energy calculations CBS-4M [36-38] method is used in 1 atm and $300 \mathrm{~K}$.

The definition of the stable energies of guest molecular cluster in host hydrate cells is given as follows. The dissociation energy $\Delta E_{\text {diss }}$ of a guest molecular cluster in hydrate cell is the energy difference between the total energy of the gas-hydrate cell and the energy summation of individual water molecules and guest molecules,

$$
\Delta E_{\text {diss }}=E_{\text {cell }}(\text { cluster })-\sum_{i}^{n} E_{\mathrm{w}, i}-\sum_{j}^{m} E_{\text {guest }, j}=\Delta E_{\mathrm{H}-\mathrm{b}}+\Delta E_{\text {cell-clst }}+\Delta E_{\text {clst }}
$$

where $E_{\text {cell }}$ (cluster) is the total energy of the hydrate cell with the guest molecular cluster inside, $E_{\mathrm{w}, i}$ is the energy of individual water molecule, and $E_{\text {guest } j \text { i }}$ is the energy of individual guest molecule. The dissociation energy $\Delta E_{\text {diss }}$ of gas-hydrate cell can be divided into three energy contributions. The first contribution is the hydrogen bond energy $\Delta E_{\mathrm{H}-\mathrm{b}}$ between water molecules in the hydrate cell, 


$$
\Delta E_{\mathrm{H}-\mathrm{b}}=E_{\mathrm{cell}}(\mathrm{empty})-\sum_{i}^{n} E_{\mathrm{w}, i}
$$

where the term $E_{\text {cell }}$ (empty) is the total energy of an empty hydrate cell. The second contribution is the interaction energy $\Delta E_{\text {cell-clst }}$ between the hydrate cell and the guest molecular cluster,

$$
{ }^{\Delta} E_{\text {cell-clst }}=E_{\text {cell }} \text { (cluster) }-E_{\text {cell }}(\text { empty })-E_{\text {clst }}
$$

where the term $E_{\mathrm{clst}}$ is the total energy of the guest molecular cluster keeping the structure inside the hydrate cell. The third contribution is the interaction energy $\Delta E_{\text {clst }}$ in the gust molecular cluster,

$$
\Delta E_{\mathrm{clst}}=E_{\mathrm{clst}}-\sum_{j}^{m} E_{\mathrm{guest}, j}
$$

The dissociation energy $\Delta E_{\text {diss }}$ of the gas-hydrate cell cannot be directly used to describe the stability of the gas-hydrate cell, because the total water hydrogen bond energies in a hydrate cell $\left(\Delta E_{\mathrm{H}-\mathrm{b}}\right)$ are in the range -800 to $-1000 \mathrm{~kJ} / \mathrm{mol}$, the interaction energies $\Delta E_{\text {cell-clst }}$ between the guest molecular cluster and the hydrate cell are in the range $-10 \sim-50 \mathrm{~kJ} / \mathrm{mol}$, and the interaction energies $\Delta E_{\mathrm{clst}}$ inside the guest molecular cluster are often less $\pm 10 \mathrm{~kJ} / \mathrm{mol}$. Small fluctuation of the hydrogen bond energy $\Delta E_{\mathrm{H}-\mathrm{b}}$ may completely conceal the contributions of the other two energy terms.

The hydrogen bond energy $\Delta E_{\mathrm{H}-\mathrm{b}}$ is the function of side length $\left(\mathrm{R}_{\mathrm{O}-\mathrm{O}}\right)$ of hydrate cell. If the side length $\left(\mathrm{R}_{\mathrm{O}-\mathrm{O}}\right)$ keeps constant, the hydrogen bond energy $\Delta E_{\mathrm{H}-\mathrm{b}}$ is a constant. The stable energy $\Delta E_{\text {stable }}$ of gas-hydrate cells is defined as follows.

$$
{ }^{\Delta} E_{\text {stable }}=E_{\text {cell }}(\text { cluster })-E_{\text {cell }}(\text { empty })-\sum_{j}^{m} E_{\text {guest } j}=\Delta E_{\text {cell-clst }}+\Delta E_{\text {clst }}
$$

In hydrate cell the interaction energy $\Delta E_{\mathrm{clst}}$ of guest molecular cluster is not always attractive (negative values). In many cases it may be repulsive (positive values) because of the small room in the hydrate cell and high electrostatic potential from the water molecules, which could change seriously with the side length $\left(\mathrm{R}_{\mathrm{O}-\mathrm{O}}\right)$ of hydrate cells.

The escaping energies $\Delta E_{\text {escape }}(\mathrm{r})$ of a hydrogen molecule (or oxygen molecule) 
from the $5^{12}$ hydrate cell are defined by the following equation,

$$
\Delta E_{\text {escape }}(r)=E_{\text {total }}\left(\mathrm{H}_{2}, r\right)-E_{\text {total }}\left(\mathrm{H}_{2}, \text { center }\right)
$$

where $E_{\text {total }}\left(\mathrm{H}_{2}\right.$, center $)$ is the total energy of a hydrogen molecule in the center of the hydrate cell, and $E_{\text {total }}\left(\mathrm{H}_{2}, r\right)$ is the total energy of a hydrogen molecule at the position $r$ from the center of the hydrate cell.

\section{Acknowledgements}

This work was supported by grant from the National Science Foundation of China (NSFC http://www.nsfc.gov.cn/) under the contract numbers 31360207 and 31370716 , and supported by Guangxi Science and Technology Development Project (no. 14123001-19 and 15104001-1). We thank the National Supper Computing Center (NSCC www.nscc-tj.gov.cn) in Tianjin for the valuable help in the calculations using TH-1A super computer. We appreciate the professional comments and the constructive suggestions of the anonymous reviewers and the editor in improving the manuscript.

\section{References}

1. S. Gao, W. House, W.G.Chapman, NMR MRI Study of Gas Hydrate Mechanisms. J. Phys. Chem. B 109 (2005) 19090-19093.

2. K.A. Kvenvolden (2000) Gas hydrate and humans. Ann. NY Acad Sci. 912, 17-22.

3. E.D. Sloan, C.A. Koh (2008) Clathrate hydrates of natural gases. $3^{\text {rd }}$ ed. CRC Press, New York.

4. Q.S. Du, D.P. Li, P.J. Liu, R.B. Huang, Molecular potential energies in dodecahedron cell of methane hydrate and dispersion correction for DFT. J. Mol. Graph. Model. 27 (2008) 140-146.

5. J.S. Gudmundsson, M. Parlaktuna, A.A. Khokhar, Storing natural-gas as frozen hydrate. SPE Prod. Fac. 9 (1994) 69-73.

6. S. Muromachi, R. Ohmura, S. Takeya, Y.H. Mori, Clathrate hydrates for ozone preservation. J. Phys. Chem. B. 114 (2010) 11430-11435.

7. S. Muromachi, T. Nakajima, R. Ohmura, Y.H. Mori, Phase equilibrium for clathrate 
hydrates formed from an ozone+oxygen gas mixture coexisting with carbon tetrachloride or 1,1-dichloro-1-fluoroethane. Fluid Phase Equilib. 305 (2011) 1452151.

8. S. Muromachi, R. Ohmura, Y.H. Mori, Phase equilibrium for ozone-containing hydrates formed from an (ozone+oxygen) gas mixture coexisting with gaseous carbon dioxide and liquid water. J. Chem. Thermodyn. 49 (2012) 126.

9. H. Mitsuda, H. Ominami, A.Yamamoto, Synergistic effect of ozone and carbon dioxide gases for sterilizing food. Proc. Japan Acad. B 66 (1990) 68272.

10. K. Koike, M. Nifuku, K. Izumi, S. Nakamura, S. Fujiwara, et al., Explosion properties of highly concentrated ozone gas. J. Loss Prev. Process Ind. 18 (2005) 4652468 .

11. T. Nakajima, T. Kudo, R. Ohmura, S. Takeya, Y.H. Mori, Molecular Storage of Ozone in a Clathrate Hydrate: An Attempt at Preserving Ozone at High Concentrations. PLoS ONE. 7 (2012) e48563.

12. N.H. Duc, F. Chauvy, J.M. Herri, $\mathrm{CO}_{2}$ capture by hydrate crystallization - a potential solution for gas emission of steelmaking industry. Energ Convers Manage 48 (2007) 1313-1322.

13. T. Nakajima, S. Akatsu, R. Ohmura, S. Takeya, Y.H. Mori, Molecular storage of ozone in a clathrate hydrate formed from an $\mathrm{O} 3+\mathrm{O} 2+\mathrm{CO} 2$ gas mixture. Angew Chem. Int. Ed. 50 (2011) 10340210343.

14. W.L. Mao, H.K. Mao, A.F. Goncharov, V.V. Struzhkin, Q. Guo, J. Hu, J. Shu, R.J. Hemley, M. Somayazulu, Y. Zhao, Hydrogen clusters in clathrate hydrate. Science 297 (2002) 2247-2249.

15. L.J. Florusse, C.J. Peters, J. Schoonman, K.C. Hester, C.A. Koh, S.F. Dec, K.N. Marsh, E.D. Sloan, Stable Low-Pressure Hydrogen Clusters Stored in a Binary Clathrate Hydrate. Science 306 (2004) 469-471.

16. Y.-T. Seo, I.L. Moudrakovski, J.A. Ripmeester, J.-W. Lee, H. Lee Efficient recovery of $\mathrm{CO} 2$ from flue gas by clathrate hydrate formation in porous silica gels. Environ Sci Technol 39 (2005) 2315-9.

17. W.L. Vos, L.W. Finger, R.J. Hemley, H.K. Mao, Novel $\mathrm{H}_{2}-\mathrm{H}_{2} \mathrm{O}$ clathrates at high pressures. Phys. Rev. Lett. 71 (1993) 3150-3153.

18. T. Sugahara, J.C. Haag, P.S. Prasad, A.A. Warntjes, E.D. Sloan, A.K. Sum, C.A. Koh, Increasing hydrogen storage capacity using tetrahydrofuran. J. Am. Chem. Soc. 131 (2009) 14616-14617.

19. S. Hashimoto, S. Murayama, T. Sugahara, H. Sato, K. Ohgaki, Thermodynamic and Raman spectroscopic studies on and tetra-n-butyl ammonium mixtures containing gas hydrates. Chem. Eng. Sci. 61 (2006) 7884-7888.

20. E.D. Sloan, Introductory overview: hydrate knowledge development. Am. Mineral. 89 (2004) 1155-1161.

21. H. Lee, J.W. Lee, D.Y. Kim, J. Park, Y.T. Seo, H. Zeng, I.L. Moudrakovski, C.I. Ratcliffe, J.A. Ripmeester, Tuning clathrate hydrates for hydrogen storage. Nature 434 (2005) 743-746.

22. T.A. Strobel, C.J. Taylor, K.C. Hester, S.F. Dec, C.A. Koh, K.T. Miller, E.D. Sloan, Molecular hydrogen storage in binary THF_H2 clathrate hydrates. J. Phys. 
Chem. B 110 (2006) 17121-17125.

23. T.A. Strobel, C.A. Koh, E.D. Sloan, Hydrogen storage properties of clathrate hydrate materials. Fluid Phase Equilibr. 261 (2007) 382-389.

24. D.Y. Kim, H. Lee, Spectroscopic identification of the mixed hydrogen and carbon dioxide clathrate hydrate. J. Am. Chem. Soc. 127 (2005) 9996-9997.

25. R.G. Grim, P.B. Kerkar, E.D. Sloan, C.A. Koh, A.K. Sum, Rapid hydrogen hydrate growth from non-stoichiometric tuning mixtures during liquid nitrogen quenching. J. Chem. Phys. 136 (2012) 234504.

26. R. Kumar, P. Englezos, I. Moudrakovski, J.A. Ripmeester, Structure and composition of $\mathrm{CO}_{2} / \mathrm{H}_{2}$ and $\mathrm{CO}_{2} / \mathrm{H}_{2} / \mathrm{C}_{3} \mathrm{H}_{8}$ hydrate in relation to simultaneous $\mathrm{CO}_{2}$ capture and $\mathrm{H}_{2}$ production. AIChE J. 55 (2009) 1584-1594.

27. I. Adamovic, M. S. Gordon, Dynamic polarizability, dispersion coefficient C6, and dispersion energy in the effective fragment potential method. Mol. Phys. 103 (2005) 379-387.

28. A.D. Becke, A new mixing of Hartree-Fock and local density-functional theories. J. Chem. Phys. 98 (1993) 1372-1377.

29. Z. Cao, J.W. Tester, B.L. Trout, Computation of the methane - water potential energy hypersurface via ab initio methods. J. Chem. Phys. 115 (2001) 2550 2559.

30. M. Head-Gordon, J.A. Pople, M.J. Frisch, MP2 energy evaluation by direct methods. Chem, Phys, Lett. 153 (1988) 503-506.

31. G.D. Purvis, R.J.A. Bartlett, Full coupled-cluster singles and doubles model: The inclusion of disconnected triples. J. Chem. Phys. 76 (1982) 1910-9.

32. T. J. Lee, J.E. Rice, An efficient closed-shell singles and doubles coupled-cluster method. Chem. Phys. Lett. 150 (1988) 406-415.

33. G.E. Scuseria, H.F. Schaefer III, Is coupled cluster singles and doubles (CCSD) more computationally intensive than quadratic configuration interaction (QCISD)? J. Chem. Phys. 90 (1989) 3700-3703.

34. G.E. Scuseria, C.L. Janssen, H.F. Schaefer III An efficient reformulation of the closed-shell coupled cluster single and double excitation (CCSD) equations. J Chem Phys. 89 (1988) 7382-7388.

35. T.H. Dunning, Gaussian basis sets for use in correlated molecular calculations. I. The atoms boron through neon and hydrogen. J. Chem. Phys. 90 (1989) 1007-1023.

36. J.W. Ochterski, G.A. Petersson, J.A.A. Montgomery Jr, Complete Basis Set Model Chemistry. V. Extensions to Six or More Heavy Atoms. J. Chem. Phys. 104 (1996) 2598.

37. J.A. Montgomery Jr, M.J. Frisch, J.W. Ochterski, G.A. Petersson, A Complete Basis Set Model Chemistry. VII. Use of the Minimum Population Localization Method. J, Chem, Phys. 112 (2000) 6532.

38. J.A. Montgomery Jr, J.W. Ochterski, M.J. Frisch, G.A.A. Petersson Complete Basis Set Model Chemistry. VI. Use of Density Functional Geometries and Frequencies. J. Chem. Phys. 110 (1999) 2822.

39. D.H. Park, B.R. Lee, J.H. Sa, K.H. Lee, Gas-hydrate phase equilibrium for 
mixtures of sulfur hexafluoride and hydrogen. J. Chem. Eng. Data. 57 (2012) 1433-1436.

40. I. Cha, S. Lee, J.D. Lee, G.W. Lee, Y. Seo, Separation of $\mathrm{SF}_{6}$ from gas mixtures using gas hydrate formation. Environ. Sci. Technol. 44 (2010) 6117-6122.

41. G.R. Qian, A.O. Lyakhov, Q. Zhu, A.R. Oganov, X. Dong, Novel Hydrogen Hydrate Structures under Pressure. Scientific Reports 4 (2014) 5606. DOI: 10.1038/srep05606.

42. T. Nakajima, T. Kudo, R. Ohmura, S. Takeya, Y.H. Mori, Molecular Storage of Ozone in a Clathrate Hydrate: An Attempt at Preserving Ozone at High Concentrations. PLoS ONE 7 (2012): e48563. doi:10.1371/journal.pone.0048563

43. J. Lunine, D. Stevenson, Thermodynamics of clathrate hydrate at low and high pressures with application to the outer solar system. Astrophys. J. Suppl. Ser. 58 (1985) 493-531.

44. Q.-S. Du, P.-.J Liu, J. Deng, Empirical Correction to Molecular Interaction Energies in Density Functional Theory (DFT) for Methane Hydrate Simulation. J. Chem. Theory. Comput. 3 (2007) 1665-1672.

45. Z. Cao, J.W. Tester, B.L.Trout, Computation of the methane-water potential energy hypersurface via ab initio methods. J. Chem. Phys. 115 (2001) 2550-2559. 
Table 1. The interaction energies of molecular clusters in gaseous phase and comparison of three methods (MP2/cc-pV5Z, CCSD/cc-pV5Z and CCSD (T)/cc-pV5Z)

\begin{tabular}{|c|c|c|c|c|c|c|}
\hline \multirow{2}{*}{ Cluster } & \multicolumn{2}{|c|}{ MP2/ cc-pV5Z } & \multicolumn{2}{|c|}{ CCSD/ cc-pVQZ } & \multicolumn{2}{|c|}{ CCSD (T)/cc-pV5Z } \\
\hline & $\Delta \mathrm{E}(\mathrm{kJ} / \mathrm{mol})$ & Structure & $\Delta \mathrm{E}(\mathrm{kJ} / \mathrm{mol})$ & Structure & $\Delta \mathrm{E}(\mathrm{kJ} / \mathrm{mol})$ & Structure \\
\hline $2 \mathrm{H}_{2}$ & -0.285 & ${ }^{\prime} \mathrm{T}^{\mathrm{a}}$ & -0.172 & ' $T$ ' a & -0.328 & $' \mathrm{~T}$ ' a \\
\hline $3 \mathrm{H}_{2}$ & -0.631 & Angle $^{b}$ & -0.299 & Angle $^{b}$ & -0.789 & Angle ${ }^{b}$ \\
\hline $\mathrm{O}_{2}-\mathrm{H}_{2}$ & -1.742 & $\mathrm{C}^{\mathrm{p}} \mathrm{a}$ & -1.365 & $\mathrm{~T}^{\mathrm{p}} \mathrm{a}$ & -1.853 & 'T ${ }^{a}$ \\
\hline $\mathrm{O}_{2}-2 \mathrm{H}_{2}$ & -2.486 & Angle $^{\mathrm{b}}$ & -2.158 & Angle ${ }^{b}$ & -3.002 & Angle ${ }^{b}$ \\
\hline $\mathrm{CO}_{2}-\mathrm{H}_{2}$ & -1.675 & Free $^{c}$ & -1.558 & Free $^{c}$ & -2.352 & Free $^{c}$ \\
\hline $\mathrm{CO}_{2}-2 \mathrm{H}_{2}$ & -3.312 & Free $^{c}$ & -2.325 & Free $^{c}$ & -3.574 & Freet $^{c}$ \\
\hline
\end{tabular}

a ' $\mathrm{T}$ ': The $\mathrm{H}_{2}$ molecule perpendicularly points to the center of the $\mathrm{O}_{2}$ molecule.

${ }^{b}$ Angle: Two $\mathrm{H}_{2}$ molecules point the center of $\mathrm{O}_{2}\left(\right.$ or $\left.\mathrm{H}_{2}\right)$ forming an angle.

${ }^{\mathrm{c}}$ Free: No special geometrical structure. 
Table 2. Interaction energies of $\mathrm{H}_{2}, \mathrm{O}_{2}$, and $\mathrm{CO}_{2}$ with water molecule $\mathrm{H}_{2} \mathrm{O}$ calculated at $\operatorname{CCSD}(\mathrm{T}) / \mathrm{cc}-\mathrm{pV} 5 \mathrm{Z}$ level.

\begin{tabular}{ccccl}
\hline $\begin{array}{c}\text { Molecular } \\
\text { clusters }\end{array}$ & $\begin{array}{c}\text { Interaction energy } \\
\mathrm{kJ} / \mathrm{mol}\end{array}$ & $\begin{array}{c}\text { Parameter } \\
(\AA)\end{array}$ & \multicolumn{2}{c}{$\begin{array}{c}\text { Aqueous solubility } \\
\mathrm{g} / \mathrm{kg}\end{array}$} \\
\hline $\mathrm{H}_{2} \mathrm{O}-\mathrm{H}_{2}$ & -0.5101 & $\mathrm{R}_{\mathrm{h}-\mathrm{o}}=2.554$ & 0.0016 & $\left(\mathrm{H}_{2}\right)$ \\
$\mathrm{H}_{2} \mathrm{O}-\mathrm{O}_{2}$ & -8.662 & $\mathrm{R}_{\mathrm{h}-\mathrm{o}}=2.528$ & 0.0430 & $\left(\mathrm{O}_{2}\right)$ \\
$\mathrm{H}_{2} \mathrm{O}-\mathrm{CO}_{2}$ & -12.719 & $\mathrm{R}_{\mathrm{c}-\mathrm{o}}=2.791$ & $0.0519 \quad\left(\mathrm{CO}_{2}\right)^{\mathrm{b}}$ \\
\hline
\end{tabular}

${ }^{\mathrm{a}} \mathrm{http} / /$ www.engineeringtoolbox.com/gases-solubility-water-d_1148.html

${ }^{\mathrm{b}}$ The solubility of $\mathrm{CO}_{2}$ at $30^{\circ} \mathrm{C}$ in water is $1.250 \mathrm{~g} / \mathrm{kg}$, includes all species $\left(\mathrm{CO}_{2}, \mathrm{HCO}_{3}{ }^{-}, \mathrm{CO}_{3}{ }^{2-}\right.$, and $\mathrm{H}_{2} \mathrm{CO}_{3}$ ). The concentration of $\mathrm{CO}_{2}$ is water is $0.0519 \mathrm{~g} / \mathrm{kg}$. 
Table 3. The interaction energies ${ }^{a}$ and stable energies of guest molecular clusters in the hydrate $5^{12}$ cell $^{\mathrm{b}}$ (side length of the dodecahedron $\mathrm{R}_{\mathrm{OO}}=2.82 \AA$ ).

\begin{tabular}{cccc}
\hline $\begin{array}{c}\text { Guest } \\
\text { cluster }\end{array}$ & $\Delta E_{\text {cell-clst }}$ & MP2/ cc-pV5Z & $\Delta E_{\text {stable }}$ \\
\hline $2 \mathrm{H}_{2}$ & -12.87 & $\Delta E_{\text {clst }}$ & -5.34 \\
$3 \mathrm{H}_{2}$ & -15.72 & 7.53 & -3.24 \\
$\mathrm{O}_{2}-\mathrm{H}_{2}$ & -28.68 & 12.48 & -23.86 \\
$\mathrm{O}_{2}-2 \mathrm{H}_{2}$ & -33.32 & 4.82 & -19.46 \\
$\mathrm{CO}_{2}-2 \mathrm{H}_{2}$ & -43.25 & 13.86 & -15.42 \\
\hline
\end{tabular}

${ }^{\text {a }}$ Energy in $\mathrm{kJ} / \mathrm{mol}$.

${ }^{\mathrm{b}}$ The positions of the guest molecules in the $5^{12}$ cell are optimized, and the side length $\left(\mathrm{R}_{\mathrm{OO}}=2.82 \AA\right)$ of the dodecahedron cell keeps constant. 
Table 4. The inner energies, enthalpy, and free energies of $\left(\mathrm{O}_{2}+2 \mathrm{H}_{2}\right)$ in $5^{12}$ hydrate cell and $\left(\mathrm{CO}_{2}+2 \mathrm{H}_{2}\right)$ in $5^{12}$ hydrate cell $\left(\mathrm{B} 3 \mathrm{LYP} / 6-311+\mathrm{G}(\mathrm{d}, \mathrm{p}), 0^{\circ} \mathrm{C}\right)$.

\begin{tabular}{llll}
\hline Molecular Group & Energy (a.u. $)^{\mathrm{a}}$ & Enthalpy(a.u.) & Free Energy (a.u.) \\
$\left(\mathrm{O}_{2}+2 \mathrm{H}_{2}\right) @ 5^{12} \mathrm{Cell}$ & -1680.755245 & -1680.753272 & -1681.147332 \\
$\Sigma(20 \mathrm{~W})$ & -1527.85376 & -1527.83646 & -1528.22276 \\
$\Sigma\left(\mathrm{O}_{2}+2 \mathrm{H}_{2}\right)$ & -152.582591 & -152.579996 & -152.626714 \\
\hline Guest-Host & $\Delta \mathrm{U}^{\circ}(\mathrm{kJ} / \mathrm{mol})$ & $\Delta \mathrm{H}^{\circ}(\mathrm{kJ} / \mathrm{mol})$ & $\Delta \mathrm{G}^{\circ}(\mathrm{kJ} / \mathrm{mol})$ \\
Interaction & -837.66 & -884.73 & -782.4 \\
\hline \hline Molecular Group & Energy (a.u. $)^{\mathrm{a}}$ & Enthalpy(a.u.) & Free Energy (a.u.) \\
$\left(\mathrm{CO}_{2}+2 \mathrm{H}_{2}\right) @ 5^{12} \mathrm{Cell}$ & -1719.164666 & -1719.163801 & -1719.264507 \\
$\Sigma(20 \mathrm{~W})$ & -1527.85376 & -1527.83646 & -1528.22276 \\
$\Sigma\left(\mathrm{CO}_{2}+2 \mathrm{H}_{2}\right)$ & -190.873089 & -190.870495 & -190.919681 \\
\hline $\mathrm{Guest}_{\mathrm{H}} \mathrm{Host}$ & $\Delta \mathrm{U}^{\circ}(\mathrm{kJ} / \mathrm{mol})$ & $\Delta \mathrm{H}^{\circ}(\mathrm{kJ} / \mathrm{mol})$ & $\Delta \mathrm{G}^{\circ}(\mathrm{kJ} / \mathrm{mol})$ \\
Interaction & -1150.04 & -1200.02 & -320.64 \\
\hline
\end{tabular}

${ }^{\mathrm{a}} 1$ a.u. $=627.509469 \mathrm{kCal} / \mathrm{mol}=2626.754637 \mathrm{~kJ} / \mathrm{mol}$ 
[Figure captions]

Figure 1. The structures of the clathrate hydrate $5^{12}$ cell. (A) The clathrate hydrate $5^{12}$ cell is a dodecahedron consisting of 20 water molecules in 12 pentagon faces. The hydrogen bond energy $\Delta E_{\mathrm{H}-\mathrm{b}}$ of 30 water-water hydrogen bonds is around -1000 $\mathrm{kJ} / \mathrm{mol}$. (B) The water van der Waals surface of the clathrate hydrate $5^{12}$ cell. The experimental side length of the clathrate hydrate $5^{12}$ cell is $\mathrm{R}_{\mathrm{O}-\mathrm{O}}=2.82 \AA$, and the diameter is $7.92 \AA$.

Figure 2. The interaction structures of $\mathrm{O}_{2}$ and $\mathrm{H}_{2}$ clusters. (A) The interaction structures of $\mathrm{H}_{2}-\mathrm{H}_{2}$ cluster is in ' $\mathrm{T}$ ' form, in which the $\mathrm{H}_{2}$ perpendicularly points to the center of the other $\mathrm{H}_{2}$ molecule. (B) The interaction structures of $\mathrm{O}_{2}-\mathrm{H}_{2}$ cluster is in ' $\mathrm{T}$ ' form, in which the $\mathrm{H}_{2}$ molecule perpendicularly points to the center of oxygen molecule. (C) The optimized structure of $\mathrm{O}_{2}-2 \mathrm{H}_{2}$ cluster is in cross form, in which the two $\mathrm{H}_{2}$ molecules perpendicularly point to the center of oxygen molecule. (D) The $\mathrm{O}_{2}-2 \mathrm{H}_{2}$ interaction structure of local minimum is in angle form, $\angle \mathrm{H}_{2}-\mathrm{O}_{2}-\mathrm{H}_{2}=60^{\circ}$ or $300^{\circ}$. The dimension $3.709 \AA \times 3.842 \AA$ at local minimum is suitable to be put in the $5^{12}$ hydrate cell. (E) The interaction structures of $\mathrm{CO}_{2}-2 \mathrm{H}_{2}$ clusters.

Figure 3. The cure of interaction energy of $\mathrm{O}_{2}-2 \mathrm{H}_{2}$ cluster as function of $\angle \mathrm{H}_{2}-\mathrm{O}_{2}-\mathrm{H}_{2}$ angle. The global minimum $(-3.217 \mathrm{~kJ} / \mathrm{mol})$ is at the position $180^{\circ}$. There two local minimums $(-3.002 \mathrm{~kJ} / \mathrm{mol})$ at positions $60^{\circ}$ and $300^{\circ}$, respectively. The dimension $3.649 \AA \times 3.889 \AA$ of the local minimum structure is suitable to be put in the $5^{12}$ hydrate cell.

Figure 4. The optimized interaction structures of $\mathrm{H}_{2}, \mathrm{O}_{2}$, and $\mathrm{CO}_{2}$ with water molecule $\mathrm{H}_{2} \mathrm{O}$. (A) The optimized structures of $\mathrm{H}_{2} \mathrm{O}-\mathrm{H}_{2}$ interaction cluster. The distance between $\mathrm{H}_{2} \mathrm{O}$ and $\mathrm{H}_{2}$ is $2.554 \AA$. (B) The optimized structure of $\mathrm{H}_{2} \mathrm{O}-\mathrm{O}_{2}$ interaction cluster. The distance between $\mathrm{H}_{2} \mathrm{O}$ and $\mathrm{O}_{2}$ is $2.527 \AA$. (C) The optimized structure of $\mathrm{HO}_{2}-\mathrm{CO}_{2}$ interaction cluster. The distance between $\mathrm{H}_{2} \mathrm{O}$ and $\mathrm{CO}_{2}$ is 2.798 $\AA$. 
Figure 5. The escaping energy $\Delta E_{\text {escape }}$ of molecule $\mathrm{H}_{2}$ and $\mathrm{O}_{2}$ from the $5^{12}$ hydrate cell. (A) The escaping energy $\Delta E_{\text {escape }}$ of molecule $\mathrm{H}_{2}$ as the function of distance $\mathrm{R}$ from the center of the $5^{12}$ hydrate cell. (B) The escaping energy $\Delta E_{\text {escape }}$ of molecule $\mathrm{O}_{2}$ as the function of distance $\mathrm{R}$ from the center of the $5^{12}$ hydrate cell. The escaping energy barrier $(\sim 160 \mathrm{~kJ} / \mathrm{mol})$ of oxygen molecule is much larger than the escaping energy barrier ( $70 \mathrm{~kJ} / \mathrm{mol})$ of hydrogen molecule. 


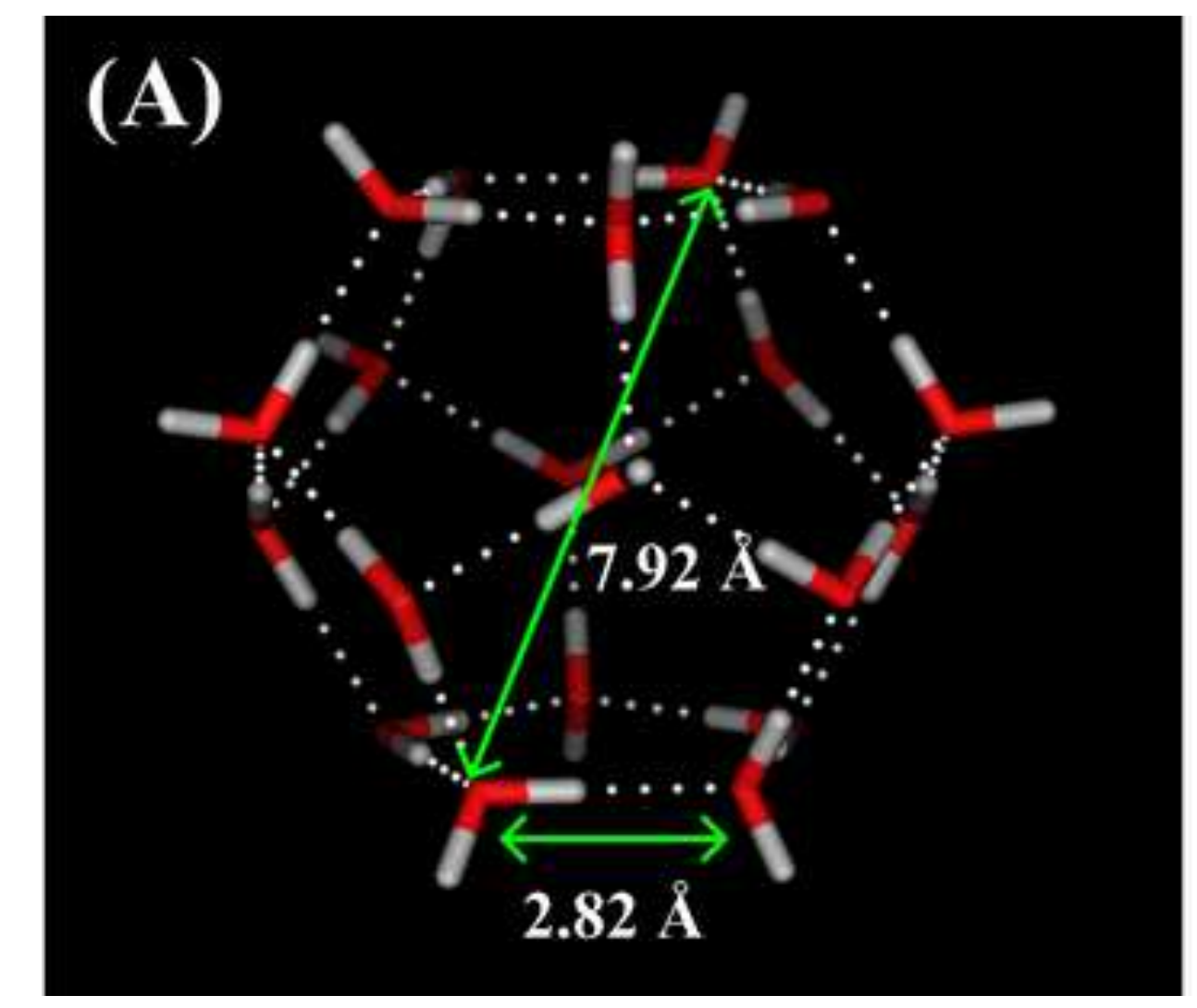

(B)

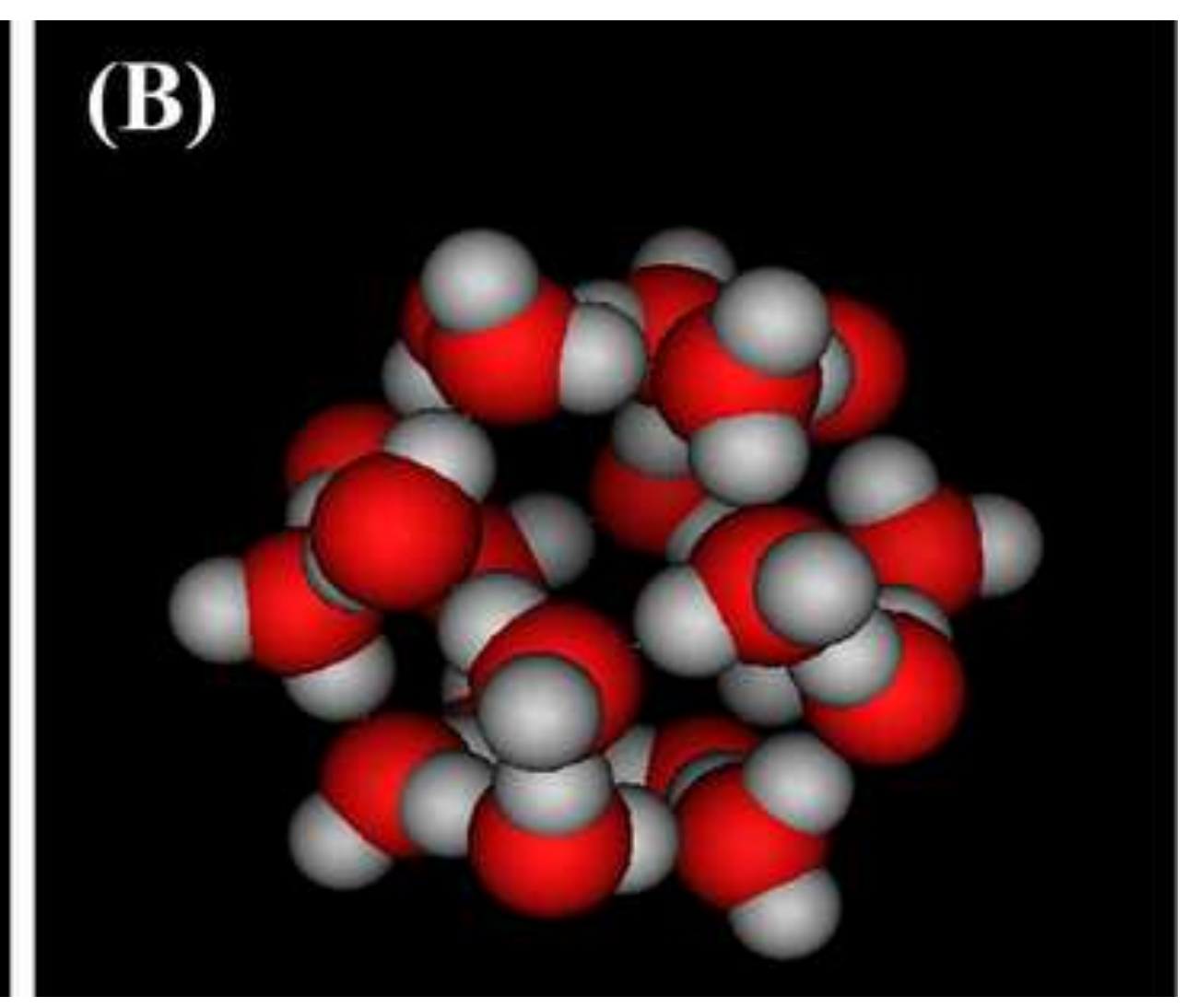




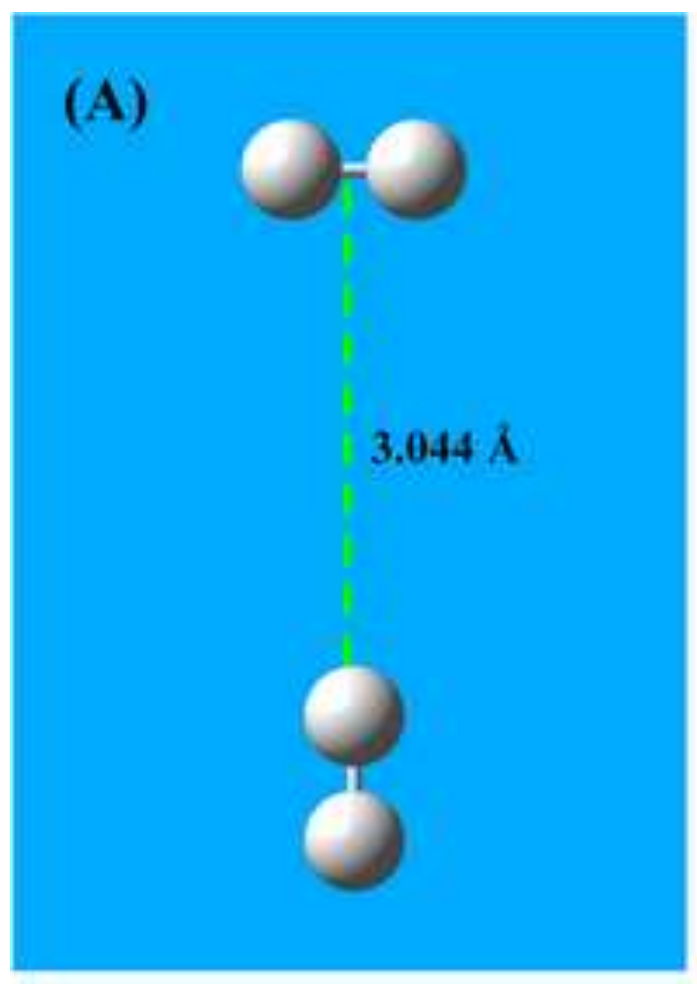

(B)

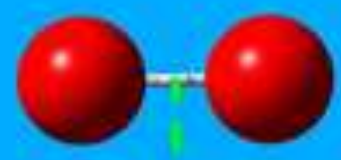

$2.812 \AA$

(C)

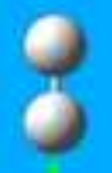

$3.152 \AA$

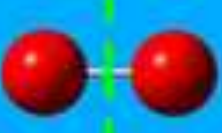

$3.152 \mathrm{~A}$

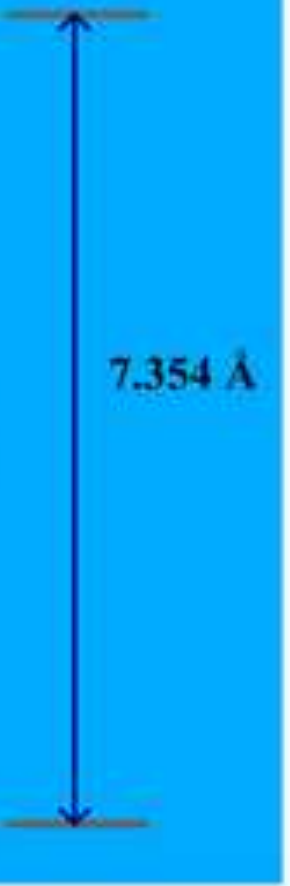

(D)

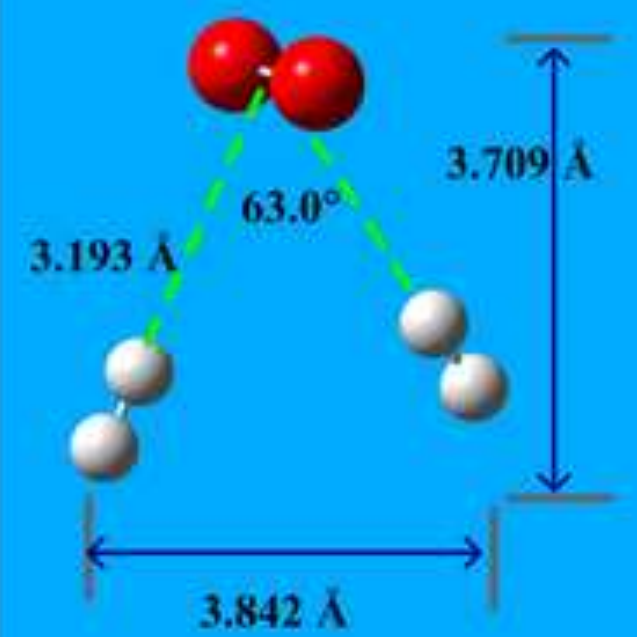

(E)

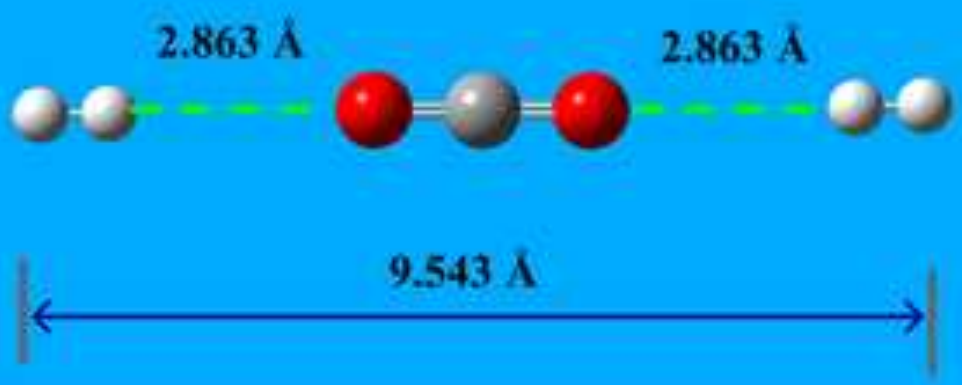




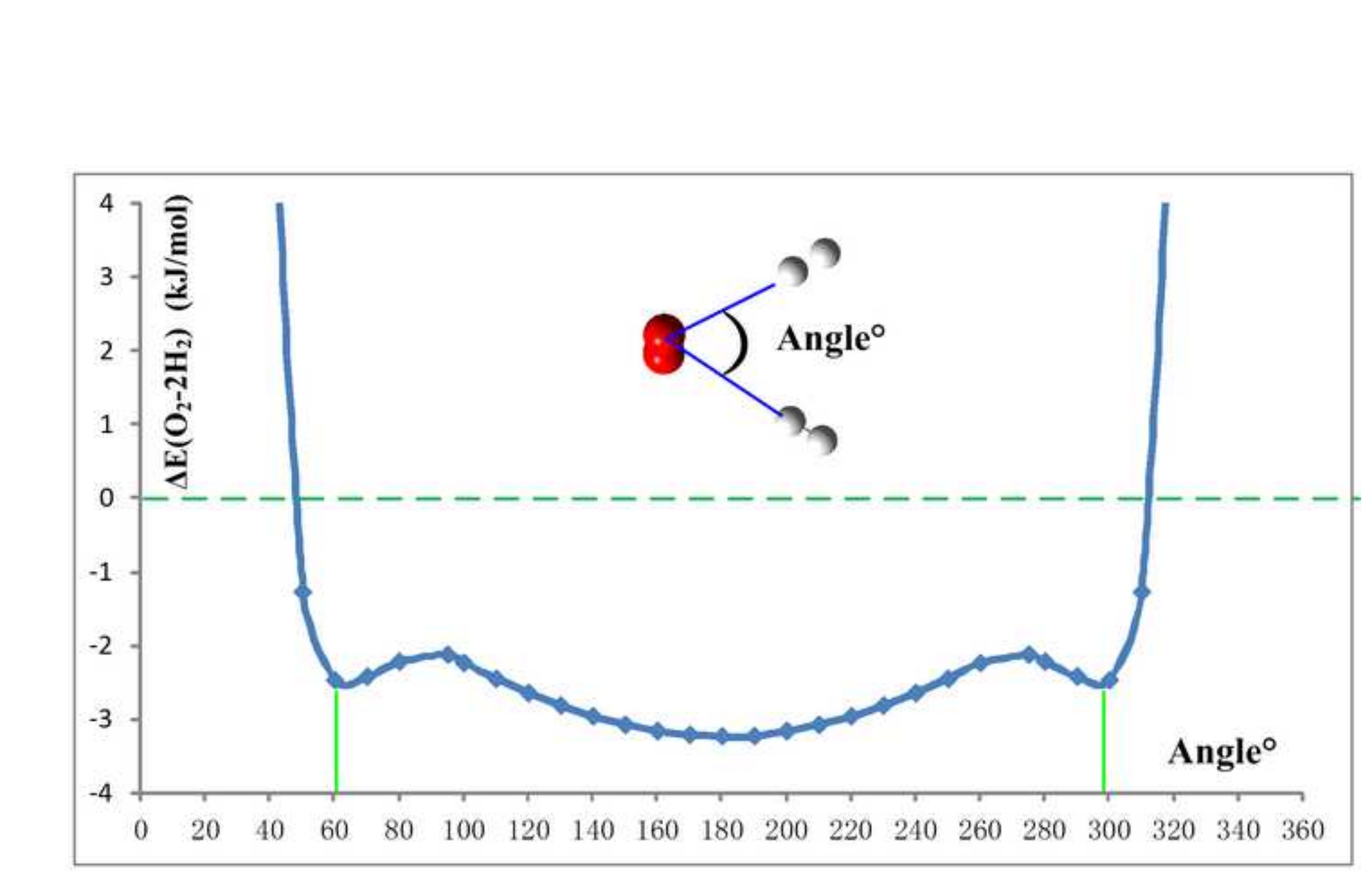


Figure-4

(A)
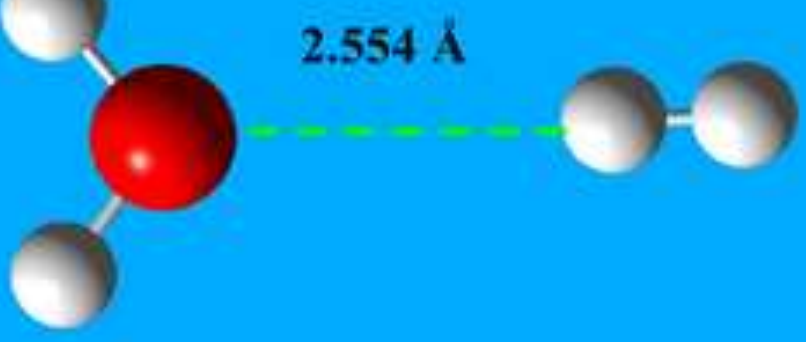

(B)

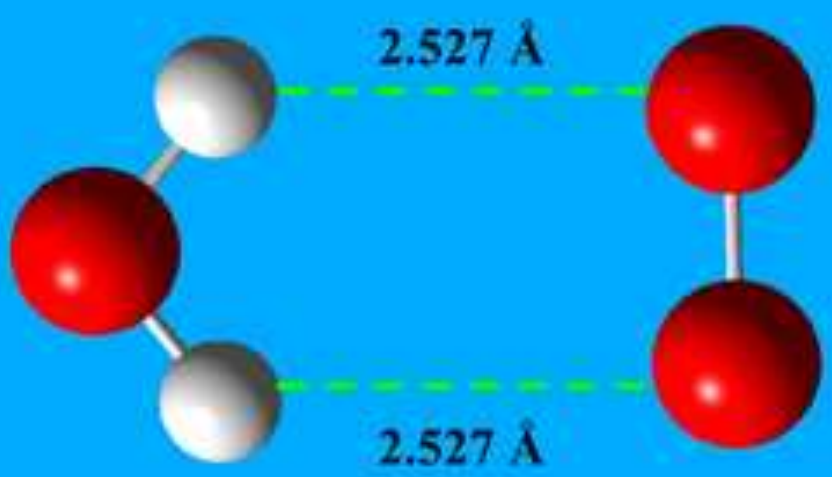

(C)

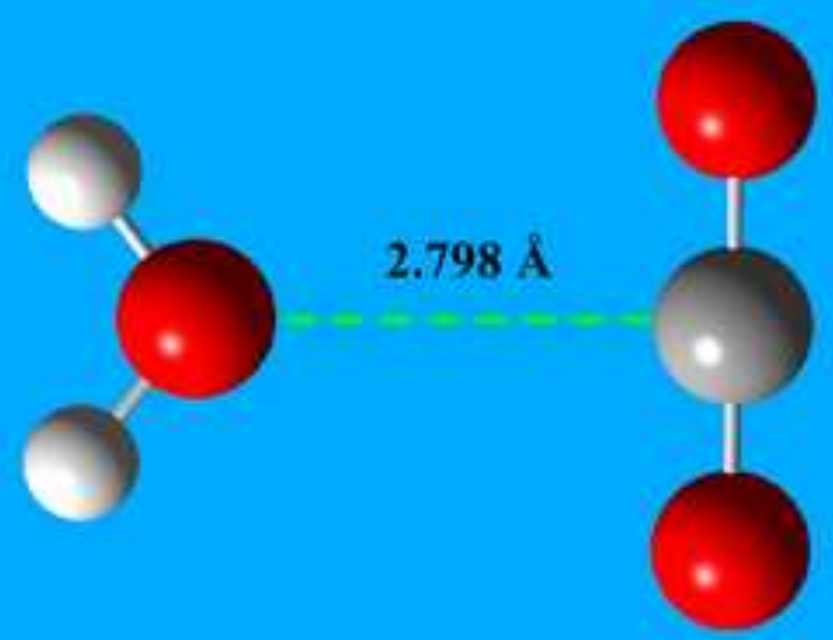



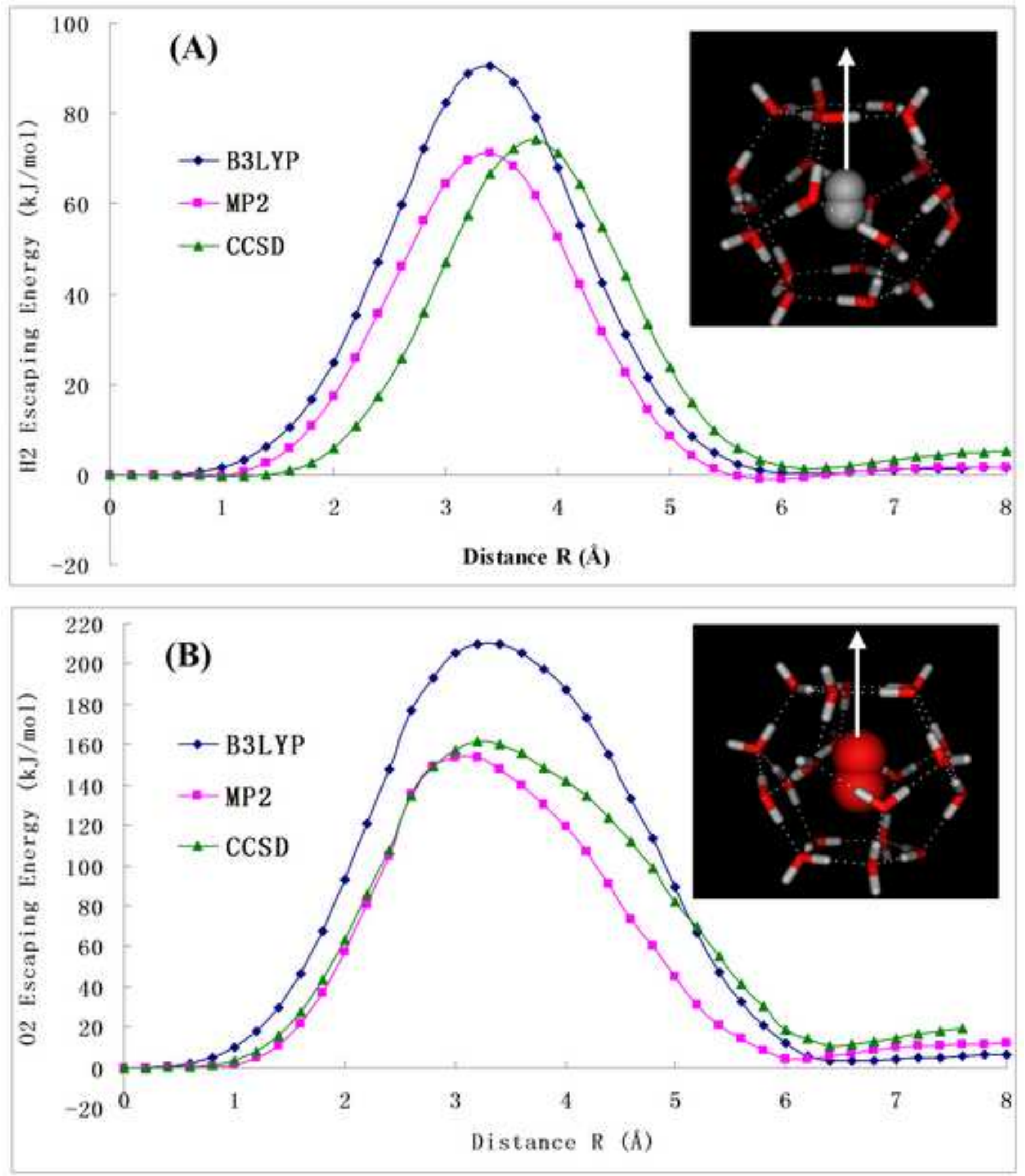
